
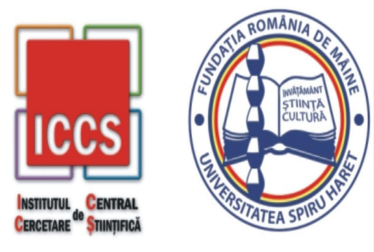

Issue 3/2019

\title{
EXPLORING THE RELATIONSHIP BETWEEN ACCOUNTING AND STATISTICS
}

\author{
Mihaela BEBEȘELEA ${ }^{1}$, Laura PATACHE ${ }^{2}$ \\ ${ }^{1}$ Spiru Haret University, Faculty of Juridical and Economic Sciences, \\ Unirii Street no. 32-34, Constanța, Romania, Tel.: 0241541490, \\ Email: mihaela.bebeselea@spiruharet.ro \\ ${ }^{2}$ Spiru Haret University, Faculty of Juridical and Economic Sciences, \\ Unirii Street no. 32-34, Constanța, Romania, Tel.: 0241541490, \\ Email: laura.patache@spiruharet.ro
}

How to cite: BEBEȘELEA, M., \& PATACHE, L. (2019). "Exploring the Relationship between Accounting and Statistics." Annals of Spiru Haret University. Economic Series, 19(3), 55-63, doi: https://doi.org/10.26458/1933

\section{Abstract}

This article highlights the connection between accounting and statistics. There is a historical connection between these quantitative methods of analysis; taking into account the fact that accounting data on property and wealth were requested in census of the great ancient civilizations. Both statistical and accounting data-setting systems provide a framework to identify, record, classify and summarize economic activities of entities.

Starting from this point of view, we have tried to understand what kind of connection exists between accounting and statistics in the current historical stage of a conform accounting: is it a univocal relationship (accounting serves to statistics or statistics serves accounting) or is it a bi-univocal relationship of reciprocity? In order to find the answer to this question we considered necessary a theoretical approach to this issue, followed by an applied one.

Keywords: accounting information; accounting data; discriminant analysis; Statev discriminant model; statistical information.

JEL Classification: M41, C10, C12, C15 


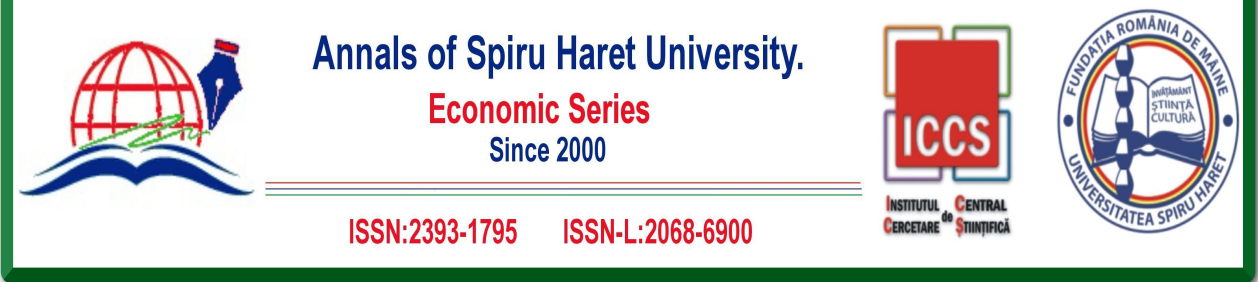

Issue 3/2019

\section{Introduction}

Accounting is one of those areas that apparently it has little in common with statistics. [Winkler, 2009] The aim of our research is to identify what kind of connection is there between accounting and statistics. In order to achieve this objective we used the theoretical and empirical research.

Through theoretical research the accounting information provided by the two ways of organizing it, respectively horizontally and vertically, but also the statistical information, as a whole, were studied. We considered this approach necessary because the accounting organized horizontally defines the spatial limits of the economic entity, as subject of patrimony, thus making it possible to identify a connection between accounting and statistics by object of study and their own methods used; while the accounting organized vertically defines the flows of economic and financial operations on national level. This way it is made possible to identify a connection between accounting and statistics: accounting providing to statistics the information regarding certain macroeconomic indicators which are published in the statistical yearbook.

Through empirical research, a discriminant analysis model was applied; the model that identifies statistics as a tool for substantiating the decision applied in accounting. Thus, by analyzing the financial data from the annual financial statements and by applying statistical discriminant models (Statev model), the probability of bankruptcy of the entity can be estimated, and also future decisions can be made.

The paper is structured into three parts: the first one reveals the theoretical background; the second one emphasizes the methodology applied, while the third one presents the results obtained.

\section{Literature Review and General Framework}

The connection between statistics and accounting is a concern for many authors. First this question is outlined: what, but especially how, can we write about statistical thinking to make it increasingly applied in accounting? What are the nature and essence of statistics? [Săvoiu, 2012] The accounting sphere of action covers two dimensions: horizontally, at economic entity level, and vertically, at national level.

The accounting organized at microeconomic level has as object of study the economic entity patrimony, which consists of all the economic assets and sources of capital.

In this respect, patrimony is studied using the accounting method. The accounting method comprises a set of principles, processes and tools that forms a whole and 56 


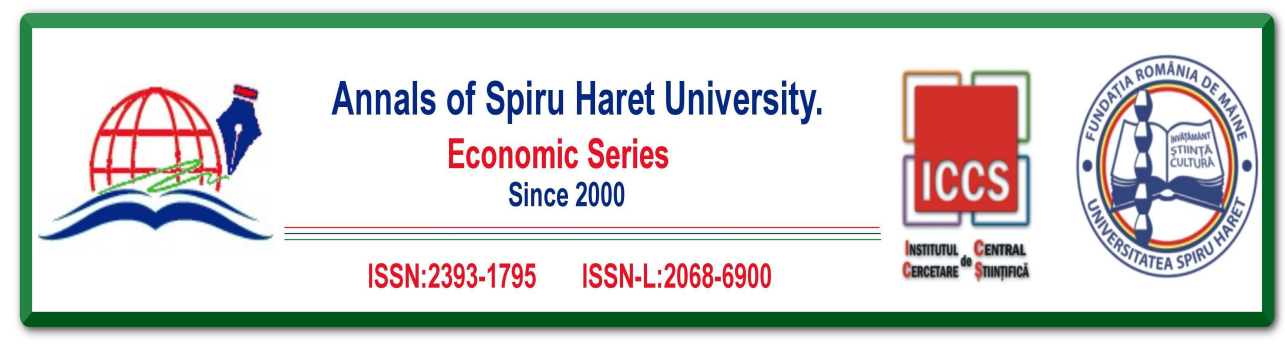

Issue 3/2019

with the help of which the patrimony of an economic entity, its state and movement are studied in order to grasp the relationships between the economic elements and, on this basis, to determine the final results. [Munteanu et al., 2014] Given the close relationship of accounting with other scientific disciplines, the tools are grouped in three categories: tools common to all sciences (observation, reasoning, comparison, analysis, synthesis), tools common to economic sciences (documentation, evaluation, calculation, inventory), and specific tools (balance sheet, account, trial balance).

The object of study of statistics is represented by the mass phenomena, which can be variables as an individual form of expression in time, in space and organizationally. [Jaba, 1998] By the way of expressing a characteristic (variable), we distinguish qualitative characteristics which are expressed through words, and quantitative characteristics that are expressed numerically and which give the data concept to statistics. The statistics data represent concrete measurements obtained from observations, measurement, counting and calculations, a fact which leads us to believe that statistics can be considered a tool of the accounting method common with other economic sciences (univocal relationship).

The accounting organized at macroeconomic level studies the flows of economic and financial operations at national level, operations related to the GDP, the size and composition of the stocks, the financial relations between different branches of the national economy and banking units, the added value at national level and the gross national surplus. All this information on macroeconomic indicators is published in the statistical yearbook, and therefore we can identify accounting as a source of information for statistics (univocal relationship).

Furthermore, by analyzing financial data comprised in the financial reporting accounting documents (the balance sheet and the profit and loss account), but also by application of statistical models, we can identify statistics as a tool for substantiating the decision applied in accounting (bi-univocal relationship of reciprocity).

Data analysis is an important initial stage in making decisions, which enables to identify the causes which lead to the emergence of a decisional situation. One of the methods used in the statistical survey in data analysis is the discriminant analysis. It belongs to the group of explanatory data analysis methods, highlighting the links between a qualitative explanatory variable and linear combinations of several quantitative explanatory variables. This method is also known in the literature as the scoring method, and it aims to establish an indicator for each economic entity called Z "score"; this score allows the estimation of the success or bankruptcy of an 


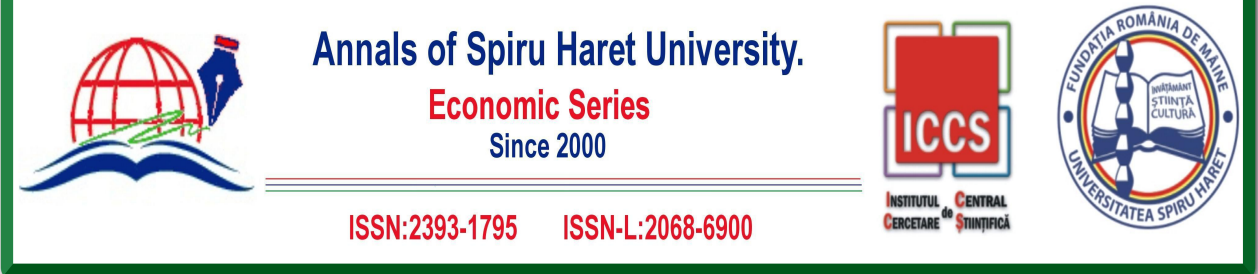

\section{Issue 3/2019}

economic entity. Scoring models were developed both abroad and in our country, and some examples are: the Altman model (1968), considered the initiator of the discriminant analysis, the Conan-Holder model (1979), the Central Bank of France model, the Anghel model (2002), the Băileşteanu model (1998), the Mânecuță model (1996) and the Statev model (2006).

Various authors have used these models in their research, either for bankruptcy risk analysis, or to obtain the audit evidence or even insolvency evidence in court. Thus, Statev (2006) believes that the discriminant analysis models makes it possible not only to determine an entity's financial status at a certain time, but also to produce estimates on the future events, based on some known data. Brîndescu-Olariu (2016), based on scoring models developed by Romanian authors, creates in his study a multivariate model applicable in the Romanian practice for corporate bankruptcy prediction. The study conducted by Brașoveanu et al. (2014) reveals the importance of discriminant analysis in increasing financial audit quality, and Jaba and Robu (2012) reveal the importance of discriminant analysis in obtaining the audit evidence. In addition, discriminant analysis is used by the companies' insolvency as insolvency evidence in court. For example, the Company by practitioners in insolvency [Solvendi, 2014], in the Report on the causes that led to the insolvency of the debtor, for the evidence of bankruptcy has applied the Statev discriminant model.

\section{Theoretical Background}

Through theoretical research we studied the subject of accounting and statistics, the accounting and statistical information, identifying a connection such as: Statistics is a tool of the accounting method or Accounting is a source collection of statistical information.

Through empirical research a connection was validated, such as: Statistics is a tool for accounting and substantiating the decision applied in accounting. We came to this conclusion by applying the discriminant analysis model, because the discriminant analysis models makes possible, not only to determine an entity's financial status at a certain time, but also to produce estimates on the future events, based on some known data. 


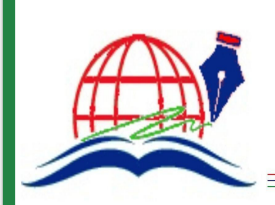

Annals of Spiru Haret University.

Economic Series

Since 2000

ISSN:2393-1795 ISSN-L:2068-6900
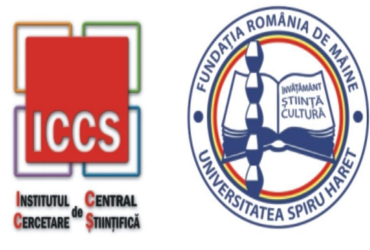

Issue 3/2019

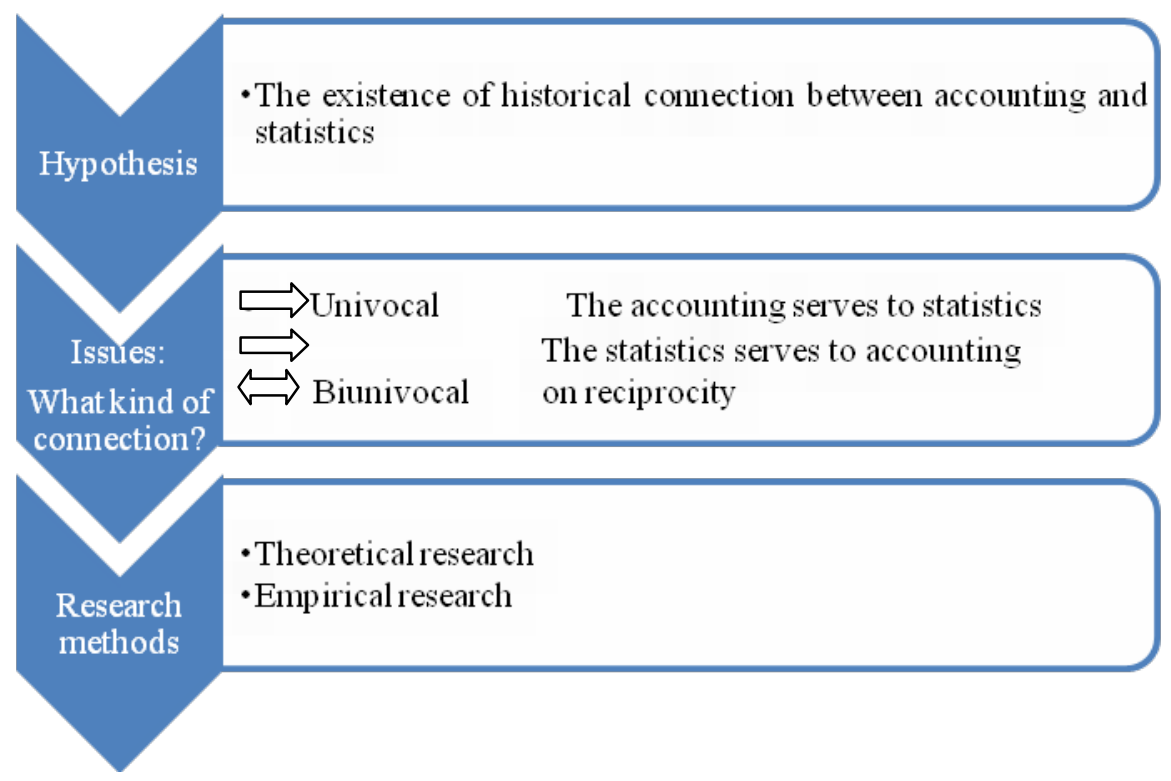

Fig. 1. Positioning the research

Source: The authors' own processing

\section{Data Issues}

The function $Z$ called "score", which is awarded to the analyzed company, is a linear combination of rates:

$$
Z=a_{1} R_{1}+a_{2} R_{2} \ldots+a_{n} R_{n}
$$

where:

$\mathrm{Ri}=$ financial parameters

ai $=$ weights coefficients

$\mathrm{i}=1$ to $\mathrm{n}-$ number of parameters

The informational support of our study is the financial data of Elcomex Agroindustrial PLC operating in the field of industrial processing of agricultural products. 


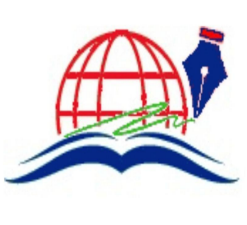

Annals of Spiru Haret University.

Economic Series

Since 2000
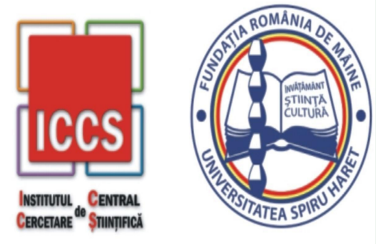

\section{Issue 3/2019}

The study materialized by putting the Statev discriminant statistical model into practice, a model applied in economic entities belonging to a branch of processing industry, with a number of employees between 10 and 500. The data were collected from financial statements related to five financial exercises, in a post crisis period, during the period 2011-2015.

The linear model of Statev for the manufacturing industry is as follows (State, 2006):

$Z_{\text {Statev }}=1.281 V_{\mathrm{g}}+1.879 V_{16}-0.386 V_{32}$

where:

$\mathrm{V}_{8}=$ Permanent capital / Total liabilities

$\mathrm{V}_{16}=$ Total debts / Total liabilities

$\mathrm{V}_{32}=$ Added value / Total assets

Based on this model, the vulnerability of the company to the value functionscore is estimated as follows:

Table 1. Decision Rule

\begin{tabular}{|c|c|}
\hline Z SCORE VALUE & FINANCIAL CONDITION \\
\hline$Z_{\text {Statev }}>1,8$ & DANGER \\
\hline$Z_{\text {Statev }} \leq 1,8$ & GOOD \\
\hline
\end{tabular}

Source: The authors' own processing based on model of Statev, 2006

\section{Empirical Results}

The Statev bankruptcy risk prediction on Elcomex Agroindustrial PLC determines the following values of the function $\mathrm{Z}$ score (Table 2).

In the analyzed entity, the function-score values are above the minimum score of 0.18 , which places the entity in a precarious financial situation throughout the period of analysis; the probability that the company goes into bankruptcy is not quite high. Nevertheless, an urgent action to redress the economic and financial situation is necessary. That is why we analyze the variables of the model.

Evolution of risk of bankruptcy during 2011-2015 and its proximity to the minimum are shown in the figure 2 .

60 


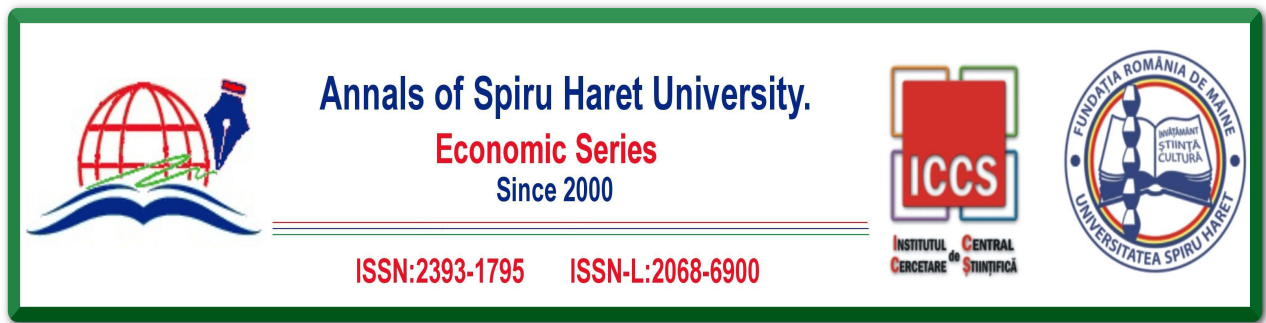

Issue 3/2019

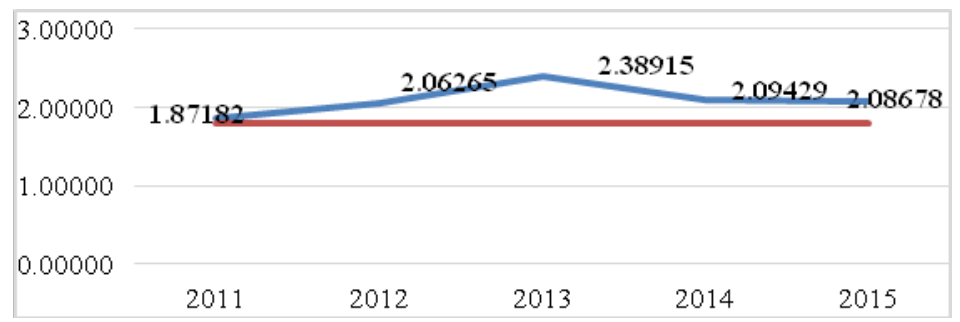

Fig. 2. The Evolution of Bankruptcy Risk and Its Proximity to the Minimum Level Source: The authors' own processing based on Elcomex Agroindustrial PLC financial data

Table 2. Determination of function Z Elcomex Agroindustrial PLC

\begin{tabular}{|l|c|c|c|c|c|}
\hline \multirow{2}{*}{$\begin{array}{l}\text { INDICATORS } \\
\text { (VARIABLES) }\end{array}$} & \multicolumn{5}{|c|}{ FINANCIAL YEAR } \\
\cline { 2 - 6 } & $\mathbf{2 0 1 1}$ & $\mathbf{2 0 1 2}$ & $\mathbf{2 0 1 3}$ & $\mathbf{2 0 1 4}$ & $\mathbf{2 0 1 5}$ \\
\hline Total Assets & $45,086,050$ & $92,691,874$ & $162,071,470$ & $214,498,672$ & $208,656,979$ \\
\hline Total Liabilities & $45,086,050$ & $92,691,874$ & $162,071,470$ & $214,498,672$ & $208,656,979$ \\
\hline Total Debts & $22,634,105$ & $55,755,179$ & $118,653,761$ & $132,256,783$ & $139,527,814$ \\
\hline $\begin{array}{l}\text { Long Time } \\
\text { Debts }\end{array}$ & $16,776,991$ & $36,253,839$ & $86,883,085$ & $76,236,310$ & $78,790,504$ \\
\hline Equity & $15,115,192$ & $30,156,517$ & $37,233,359$ & $76,653,366$ & $56,681,043$ \\
\hline $\begin{array}{l}\text { Permanent } \\
\text { Capital }\end{array}$ & $31,892,183$ & $66,410,356$ & $124,116,444$ & $152,889,676$ & $135,471,547$ \\
\hline Sold Production & $2,811,288$ & 555,229 & $2,290,055$ & $19,691,121$ & $52,027,358$ \\
\hline $\begin{array}{l}\text { Stock } \\
\text { Production }\end{array}$ & 560,239 & $3,781,942$ & $12,585,083$ & $21,990,111$ & $1,762,220$ \\
\hline $\begin{array}{l}\text { Capitalized } \\
\text { Production }\end{array}$ & $1,500,000$ & $3,322,043$ & $6,460,020$ & $12,676,394$ & - \\
\hline Production Year & $4,871,527$ & $7,659,214$ & $21,335,158$ & $54,357,626$ & $53,789,578$ \\
\hline $\begin{array}{l}\text { Material } \\
\text { Expenses }\end{array}$ & $2,255,112$ & $4,146,827$ & $7,672,711$ & $41,756,561$ & $54,533,400$ \\
\hline Added Value & $2,616,415$ & $3,512,387$ & $13,662,447$ & $12,601,065$ & $-743,822$ \\
\hline V & 0.70736 & 0.71646 & 0.76581 & 0.71277 & 0.64925 \\
\hline V & 0.50202 & 0.60151 & 0.73210 & 0.61658 & 0.66869 \\
\hline V & 0.05803 & 0.03789 & 0.08429 & 0.05874 & -0.00356 \\
\hline $\begin{array}{l}\text { Function Z } \\
\text { score }\end{array}$ & $\mathbf{1 . 8 7 1 8 2}$ & $\mathbf{2 . 0 6 2 6 5}$ & $\mathbf{2 . 3 8 9 1 5}$ & $\mathbf{2 . 0 9 4 2 9}$ & $\mathbf{2 . 0 8 6 7 8}$ \\
\hline
\end{tabular}

Source: The authors' own processing based on Elcomex Agroindustrial PLC financial data 

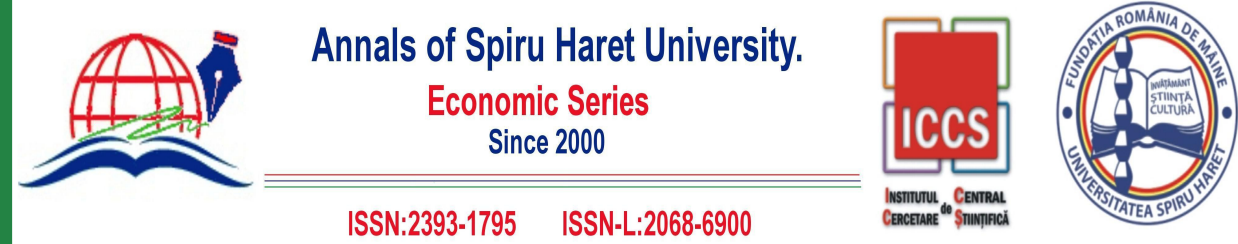

\section{Issue 3/2019}

Finally, the function Z score of Elcomex Agroindustrial PLC was validated by discriminant analysis for the classification of the financial condition of the company in "good" or "danger". We find that function-score values are below the minimum score of 0.18 , which places the entity in danger. The score is a simple tool for "early detection" of default risk and investment opportunities, but this information should be used with caution. In order to reach a proper decision regarding the financial soundness of a company, the analysis should be supplemented by observing the evolution of the score for the company over several years, and in comparison with traditional methods of financial analysis.

\section{Conclusions}

The paper highlighted that between accounting and statistics is a bi-univocal relationship, a mutual dependency. National accounting is a source in collection of statistical information, and statistics can be considered, for the accounting organized at microeconomic level, a tool of the accounting method.

In addition to that, statistics is a tool for accounting and substantiating the decision applied in accounting; that is because the discriminant analysis models make it possible, not only to determine an entity's financial status at a certain time, but also to produce estimates on the future events (decisions), based on some known data.

The financial data of Elcomex Agroindustrial PLC, processed and interpreted by the Statev model, had placed the company in danger of bankruptcy. In fact, since 2016, the company has begun the financial reorganization as a consequence of the insolvency procedure.

The hypothesis that it is a connection between accounting and statistics is confirmed, first one univocal, demonstrated by theoretical research and then one biunivocal, and demonstrated by Statev discriminant model.

\section{References}

[1] Altman, E. (1968). Financial Ratios, Discriminant Analysis and the Prediction of Corporate Bankruptcy. The Journal of Finance, 23(4), 589-609.

[2] Anghel, I. (2002). "Falimentul - radiografie și predicție," Economica.

[3] Băileșteanu, Gh., Diagnostic, risc şi eficienţă în afaceri, Mirton, 1998.

[4] Braşoveanu, I.V., Dobre, F. \& Brad, L. (2014). "Increasing Financial Audit Quality Using a New Model to Estimate Financial Performance," Romanian Journal of Economic Forecasting, 17(3), 88-107. 

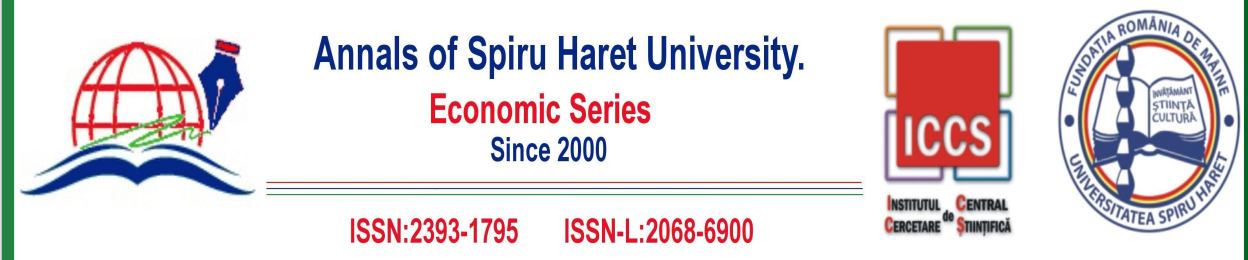

Issue 3/2019

[5] Brîndescu-Olariu, D. (2016). "Multivariate Model for Corporate Bankruptcy Prediction in Romania," Network Intelligence Studies, 4(7), 69-83.

[6] Conan, J. \& Holder, M. Variables explicatives de performance et controle de gestion dans les P.M.I. (Explanatory variables of performance and management control in P.M.I.), Universite Paris Dauphine, 1979.

[7] Jaba, E., Statistică, Economica, 1998.

[8] Jaba, E. \& Robu, I.B. (2009). "The Use of the Discriminant Analysis for Obtaining Audit Evidence (II)," Revista Audit financiar, 12, 19-26.

[9] Mânecuță, C. \& Nicolae, M. (1996). "Building and Using the Score Function to Diagnose the Efficiency of Economic Agents." Finanţe, Credit, Contabilitate, 5, 47-54.

[10] Munteanu, V. et al., Bazele contabilității. Ediția a II-a, Universitara, 2014.

[11] State, V. (2006). Determination of Enterprise's Financial Status by Statistical Discriminant Models - Statev Model. Annales Universitatis Apulensis Series Oeconomica, 8(2).URL: http://www.oeconomica.uab.ro/upload/lucrari/820062/50.pdf

[12] SOLVENDi. (2014). Report on the Causes and Circumstances that Led to the Insolvency of the Debtor. URL: solvendi.ro/downloadCauze.php?id=235

[13] Winkler O.W., The Interface between Statistics and Accounting. In: Interpreting Economic and Social Data. Springer, 2009. 
